\title{
LTAI Management Based on Blockchain Technology to Increase Alexa Rank
}

\author{
Petrus Sokibi ${ }^{1}$, Marsani Asfi ${ }^{2}$, Qurotul Aini ${ }^{3}$, Alfiah Khoirunisa ${ }^{4}$, Untung Rahardja ${ }^{5}$ \\ ${ }^{1}$ Master of Information System Department, STMIK Catur Insan Cendekia, petrus.sokibi@cic.ac.id \\ ${ }^{2}$ Master of Information System Department, STMIK Catur Insan Cendekia, marsani.asfi@cic.ac.id \\ ${ }^{3}$ Master of Information System Department, Universitas Raharja, aini@raharja.info ${ }^{3}$ \\ ${ }^{4}$ Master of Information System Department, Universitas Raharja, alfiah@ raharja.info \\ ${ }^{5}$ Master of Information System Department, Universitas Raharja, untung@ @aharja.info
}

\begin{abstract}
The development of technology and information that is taking place today has an impact on the creation of many online community websites that circulate, providing various kinds of information that are served and packaged in as attractive a form as possible, such as the Alphabet Incubator Website. Alphabet Incubator has a lot of information contained in the use of the blockchain in LTAI's schedule management. The Alphabet Incubator website is a corporate creative preneur-based startup community website. Alphabet Incubator has a goal with a very high potential to manage the increased traffic rank of the Alphabet Incubator website as seen from its LTAI schedules. Blockchain research in recent years has produced a need to conduct research studies. As this research goes on, there are 3 (three) problems that are being faced regarding the management of increasing Alphabet Incubator website traffic rank by visiting the Alphabet Incubator website to make LTAI schedule management. In the stage of improving quality, blockchain is utilized in the LTAI schedule on the Alphabet Incubator website. To measure the traffic rank of the Alphabet Incubator website and to support the development of the Alphabet Incubator, the implementation is carried out by using the blockchain on the LTAI schedule that has been made by students. Resulting in blockchain utilization activities on the LTAI schedule and for the management of increasing Alphabet Incubator website rankings using Alexa Rank.
\end{abstract}

Key words: Finalization, assessment, comprehensive session, management.

\section{INTRODUCTION}

When the development of the digital 4.0 era has explored all fields, both in the fields of education, technology, and other fields [1]. All fields have been supported by technology [2]. The use of technology in various sectors can already be applied and what is currently growing rapidly is technology on various websites. Blockchain technology is strong like the internet, but not like the internet web today. Blockchain stores blocks of identical information throughout the network [3]. In this approach the blockchain is used to manage transactions, content, teaching, and competence [4]. Blockchain technology has received considerable attention, ranging from data management, cybersecurity and brain research science [5]. Through blockchain technology, Chain Soft allows users to create and send software including automatic code verification in making LTAI schedules on the Alphabet Incubator website [6]. Alphabet Incubator is a Research Center that acts as an enterprise that has an ecosystem to successfully deliver corporate startup entrepreneurs. With the development of technology and information that is very fast, so the internet has revolutionized several aspects of life, society, and business. Specific blockchain in advanced technology set-up [7]. Blockchain is now believed to be a component that complements the internet puzzle by making it more open, more accessible and more reliable [8]. For example, information that is the source of many changes in daily life. Information can also be said as one for the needs of an agency, organization, company, institution and also the environment that is outside the system. Information circulating in cyberspace certainly presents a lot of interest with various types and various forms that are usually displayed in the summary of an article with the aim to be presented with websites that are in cyberspace to attract many visitors is useful to increase the rank number on the website. The rank on a website is considered to have an influence on the survival of the website, because if the higher rank of a website then it will give other visitors confidence to visit the website. To achieve this, of course a strategy is needed to achieve the desired increase in rank and activities on the website, an activity that often occurs is the use of an article which is considered to cause discussion like comments which means there are visitors coming to the website [9]. One such assessment is looking at the level of popularity of the website 
Petrus Sokibi et al., International Journal of Advanced Trends in Computer Science and Engineering, 9(4), July - August 2020, 4798 - 4802

[10]. Rise and fall of rank levels on a website can be very easily seen with Alexa, which ranks rank on the website that will be useful to facilitate users (web) and find out information about the ranking or ranking of a site, influenced by the amount of traffic or visitors who enter on site.

There are various strategies that can be done to increase the value of traffic rank on the Alphabet Incubator website, namely by making a schedule of the LTAI. There is a quote quoted from the website that explains about traffic rank, that is, a website can use articles as a website promotion site to increase visitor attention and increase page rank, the concept of website marketing with articles can be considered popular. Not a few site owners who produce articles that are written and published in many article directories, with a simple reason, namely to increase traffic rank.

The Alphabet Incubator website is one of the websites that utilize blockchain on LTAI schedule to increase traffic rank. The website is a startup community website which is also a place for activity information contained in the Alphabet Incubator.

\section{RESEARCH METHOD}

Raharja University as an institution that deals with the world of education is considered to have a large enough community to have a startup community website [11]. Alphabet Incubator which is used as a place to exchange information containing LTAI about learning streaming with more dominance found on the Alphabet Incubator website. In recent years, blockchain technology has grown to be financially viable. One of them on the Alphabet Incubator website is the activity of using blockchain on LTAI schedule [12]. Alphabet Incubator is a startup community website with a variety of activities that are considered to have ranking potential with a large enough value and the implementation of several strategies that are deemed to meet to increase traffic rank on the Alphabet Incubator website.

But the activities on the existing Alphabet Incubator have not been able to provide satisfactory results in raising the Alphabet Incubator rank because in terms of Alphabet Incubator's activity is still not optimal, the Alphabet Incubator website is visited by many students who want to do LTAI just to do the work the assignments of the course are making LTAI schedules on the Alphabet Incubator web, it can be imagined how much use of the blockchain on the LTAI schedule is on the Alphabet Incubator web, but the use of the blockchain on the LTAI schedule that is already owned by the large number of schedules that are assessed cannot provide the maximum benefit to increase the Alphabet Incubator web traffic rank, meaning that the interest of students to make LTAI schedules on the Alphabet Incubator web is still considered to be not optimal. So to increase web traffic rank Alphabet Incubator requires a number of strategies that must be carried out and managed well for the use of blockchain on LTAI schedules. LTAI in the Alphabet Incubator web with a considerable amount of value is not utilized properly and maximally. Alphabet Incubator cannot add more activities, meaning the
Alphabet Incubator web can only create LTAI activity schedules without adding more activities.

\subsection{Literature Review}

The existence of a literature study method (literature review) is carried out to support research and the use of observation and interview methods that have been conducted. The collection of information that is considered important in finding references that are related to the research conducted. There have been many researchers who made observations regarding the system of increasing traffic and other research. The existence of a literature study (literature review) is to identify gaps, also continue research that has previously been done and avoid any remake.

The first research was conducted by Untung Rahardja, Qurotul Aini, and Yuliana Isma Graha in 2019 with the title "Implementation of Gamification into Management of Education for Motivating Learners". Explained that there are many tools that can be used from this Rinfo such as Rinfo Docs which can be used to support the course of learning so as to make students more interested in doing learning online [13]. Subsequent research was conducted by Rahayu Widayanti (2015). In this research about "Analysis of the Website of Goods Shipping Services Company Using Alexa Rating Tool" The research has the aim to analyze the website of a freight forwarding service company with Alexa ranking tools [14]. Research conducted by Untung Rahardja, Qurotul Aini, Lily Ratna Sulastri, in 2017 entitled "The Implementation of Inbound Official Site Information Systems to Increase Webometrics Rank". The discussion of this study explains the problems faced namely inbound for an Information Systems website. The final decision of this study uses webometrics to monitor rank values on the website raharja.ac.id [15]. A study conducted by Zyskind, G., \& Nathan, O. (2015), entitled "Decentralizing privacy: Using blockchain to protect personal data". This study describes a decentralized personal data management system that ensures users own and control their data. We implemented a protocol that transformed the block chain into an automatic access control manager that did not require trust in third parties [16]. A study conducted by Samaniego, M., \& Deters, R. (2016), entitled "Blockchain as a Service for IoT". This research is to manage device configuration, save sensor data and activate micro payments. Which presents the idea to use blockchain as a service for IoT and evaluate the performance of cloud and edge blockchain implementations [17]. A study conducted by Huckle, S., Bhattacharya, R., White, M., \& Beloff, N. (2016), entitled "Internet of things, blockchain and shared economy applications". This research discusses how exploring the Internet of Things and blockchain technology can benefit joint economic applications [18]. A study conducted by Wright, A., \& De Filippi, P. (2015), entitled "Decentralized blockchain technology and the rise of lex cryptographia". This research is about Blockchain which enables the development of new governance systems with more democratic or participatory, and decentralized (autonomous) decision making that can operate through computer networks 
Petrus Sokibi et al., International Journal of Advanced Trends in Computer Science and Engineering, 9(4), July - August 2020, 4798 - 4802

without human intervention [19]. Research conducted by Giuseppe Di Battista, et al (2015) in his journal entitled "Bitconeview: visualization of flows in the bitcoin transaction graph". In his journal the author explains digital currencies stored in a ledger called a blockchain [20][22][23].

From the 8 (eight) existing literature studies, there are so many studies that discuss the use of information technology advancements that are considered to be able to improve effectiveness in the management field, both utilization in the field of entrepreneurship and learning. Then, it can be concluded that there are no researchers who focus on discussing the use of a page on a website such as LTAI based on blockchain technology to increase rank on that website.

\section{FINDINGS}

After observing and examining the 3 (three) problems that occur with the current system, of course after this research, the existing problems can be resolved properly and the Alphabet Incubator web runs smoothly so that it can be used as information media. To support learning methods especially Startup, Entrepreneurship, with the many activities in it can be able to provide student interest, knowledge and insight to increase the traffic rank of the Alphabet Incubator website. Utilizing the LTAI blockchain schedule that is very easy on the Alphabet web is obtained every time doing activities on the Alphabet Incubator web, one of which is to make an LTAI schedule. In solving this problem blockchain uses encryption technology in LTAI schedule code [24][25][26]. Utilizing the blockchain on the LTAI schedule to improve the website of the Alphabet Incubator is proven to be influential in increasing website rank. Discuss with students to find out more about LTAI so as to make a schedule on the Alphabet Incubator website. Making LTAI schedules that are very easy on the Alphabet Incubator website can be done to carry out LTAI activities contained on the Alphabet Incubator website.

\subsection{Research Implementation}

Display implementation of the Alphabet Incubator website which has various features to be used by users.

\section{A. Display Home on the Alphabet Incubator}

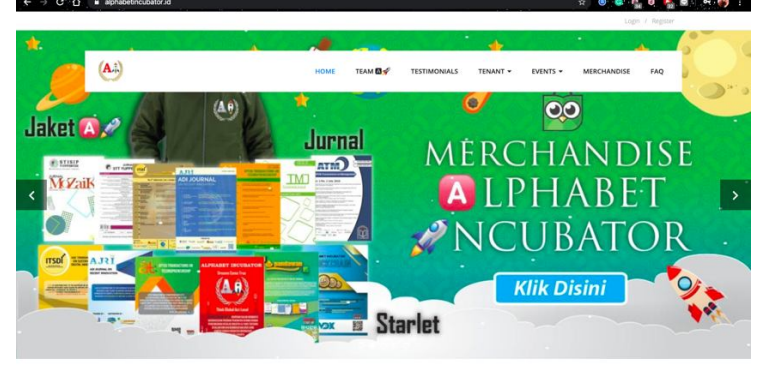

Figure 1: Display Home on the Alphabet Incubator

Figure 1 is the home view of the alphabet incubator website, as this website should be made with a simple but friendly and informative display in order to attract the attention of visitors, this is a strategy used to increase rankings of visitors on the website.
B. Display the Login Menu on the Alphabet Incubator

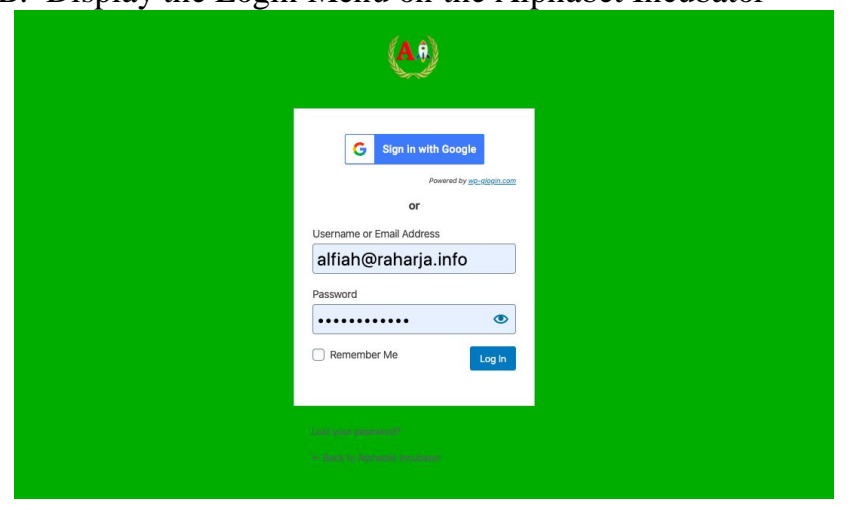

Figure 2: Display the Alphabet Incubator Login Page

C. Required to use Rinfo Email

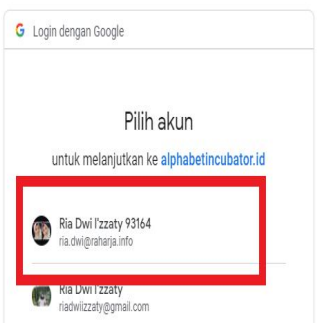

Figure 3: Login Info

D. Display the LTAI Menu

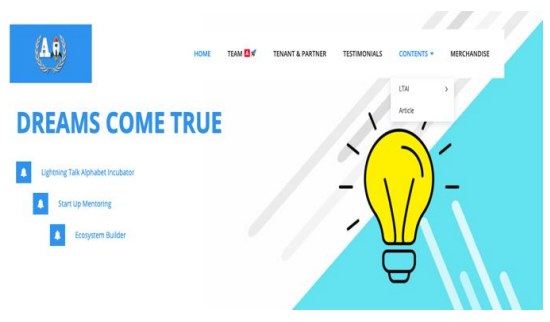

Figure 4: LTAI Menu Display

E. Display Script on LTAI Schedule

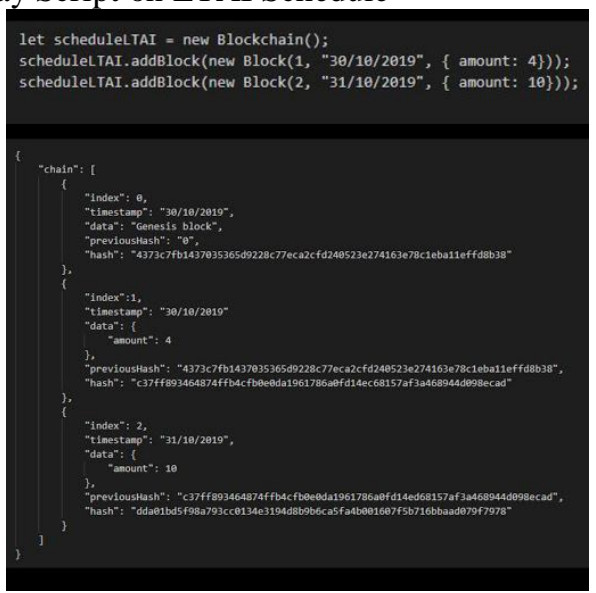

Figure 5: Display Script on LTAI Schedule

Figure 5 is a blockchain script that is embedded into the LTAI schedule scheduling with the aim that the schedule cannot be manipulated and summarized well as the nature of blockchain in general is safe and cannot be erased. This gives a safe impact on the existing schedule and avoids the conflicting 
Petrus Sokibi et al., International Journal of Advanced Trends in Computer Science and Engineering, 9(4), July - August 2020, 4798 - 4802

schedule on LTAI registered by visitors because each schedule has a different code..

F. Display the LTAI Schedule sub menu

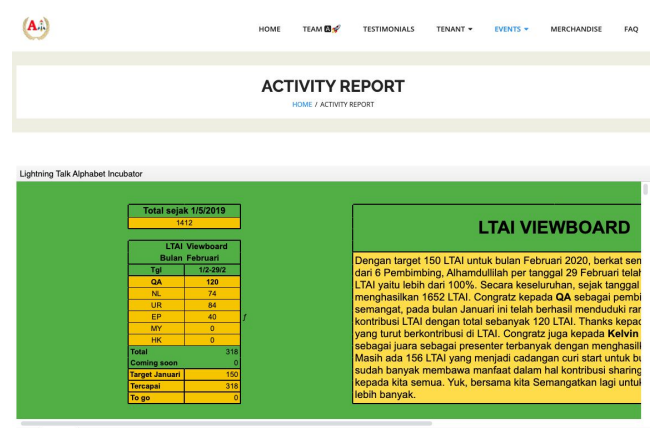

Figure 6: Display of LTAI Schedule sub menu

G. Display Google Calendar

\section{+ Google Calendar}

Figure 7: Display Google Calendar

To create a FLOOR schedule.

\section{CONCLUSION}

Based on LTAI research based on blockchain technology to increase alexa rank on the Alphabet Incubator web there are 3 (three) conclusions, including:

Increasing activities on the Alphabet Incubator web through blockchain-based LTAI technology to increase alexa rank requires a moderator as a manager in socializing LTAI schedules so that maximum activity can occur on the Alphabet Incubator web.

Increasing the Alphabet Incubator rank for LTAI based on blockchain technology requires activities on the Alphabet Incubator such as creating the LTAI schedule and the schedule function to greatly affect the Alphabet Incubator web rank value [27].

Increasing student interest can make LTAI schedule requests on the Alphabet Incubator web. Several strategies are needed to attract student interest, because LTAI schedules are not yet optimal and dominate more with students who make LTAI schedules only to do assignments given by lecturers. Without giving more activities. On the Alphabet Incubator website that has been created, so that to attract students needs a pretty interesting strategy [28].

The author would like to thank STMIK Catur Insan Cendekia, for financial support and for providing a place to support this research through research system analysis.

\section{REFERENCES}

1. Rahardja, U., Hariguna, T., \& Baihaqi, W. M. (2019, August). Opinion Mining on E-Commerce Data Using Sentiment Analysis and K-Medoid Clustering. In 2019
Twelfth International Conference on Ubi-Media Computing (Ubi-Media) (pp. 168-170). IEEE.

2. Rahardja, U., Aini, Q., \& Khoirunisa, A. (2018). Effect of iDu (iLearning Education) on Lecturer Performance in the Lecture Process. Aptisi Transactions On Management, 2(2), 140-148.

3. Bambara, J. J., Allen, P. R., Iyer, K., Madsen, R., Lederer, S., \& Wuehler, M. (2018). Blockchain: A practical guide to developing business, law, and technology solutions. McGraw Hill Professional.

4. Lizcano, D., Lara, J. A., White, B., \& Aljawarneh, S. (2019). Blockchain-based approach to create a model of trust in open and ubiquitous higher education. Journal of Computing in Higher Education, 1-26.

5. Rahardja, U., Aini, Q., \& Meytasari, R. (2017). Pemanfaatan Fungsi Etalase Artikel Untuk Meningkatkan Traffic Rank Website ZPreneur. Technomedia Journal, 1(2), 76-89.

6. Novita, D., \& Fransen, L. A. (2017). ANALISIS POPULARITAS WEBSITE PEMERINTAH KOTA DI SUMATERA SELATAN. In Seminar Nasional \& Konferensi Sistem Informasi, Informatika \& Komunikasi STIKOM Uyelindo Kupang 2017 (pp. 414-419). STIKOM UYELINDO KUPANG.

7. Rahardja, U., Aini, Q., \& Putri, D. M. (2018). Pemanfaatan Automated Email System (AEMS) Sebagai Media Notifikasi Penilaian Hasil Belajar. SENSITEK, 1(1), 49-54.

8. Rahardja, U., Aini, Q., Graha, Y. I., \& Khoirunisa, A. (2019, May). Implementation of Gamification into Management of Education for Motivating Learners. In Proceeding Interuniversity Forum for Strengthening Academic Competency (Vol. 1, No. 1, pp. 209-209)..

9. Rahardja, U., Hidayanto, A. N., Hariguna, T., \& Aini, Q. (2019). Design Framework on Tertiary Education System in Indonesia Using Blockchain Technology. In 2019 7th International Conference on Cyber and IT Service Management, CITSM 2019. Institute of Electrical and Electronics Engineers Inc. https://doi.org/10.1109/CITSM47753.2019.8965380.

10. Handayani, I. (2014). BUILDING MARKETING UNTUK KOMUNITAS SENDIRI BERBASIS ONLINE. CCIT Journal, 7(3), 464-479

11. Rahardja, U., Aini, Q., \& Sulastrini, L. R. (2017). Penerapan Inbound Official Site Sistem Informasi Untuk Meningkatkan Rank Webometrics. Technomedia Journal, 1(2), 105-115.

12. Rahardja, U., Lutfiani, N., \& Juniar, H. L. (2019). Scientific Publication Management Transformation In Disruption Era. Aptisi Transactions on Management (ATM), 3(2), 109-118. https://doi.org/10.33050/atm.v3i2.1008

13. Rahardja, U., Aini, Q., Graha, Y. I., \& Khoirunisa, A. (2019, May). Implementation of Gamification into Management of Education for Motivating Learners. In Proceeding Interuniversity Forum for Strengthening Academic Competency (Vol. 1, No. 1, pp. 209-209). 
Petrus Sokibi et al., International Journal of Advanced Trends in Computer Science and Engineering, 9(4), July - August 2020, 4798 - 4802

14. Widayanti, R., \& Utsalina, D. S. (2015). ANALISIS SITUS WEB PERUSAHAAN JASA PENGIRIMAN BARANG MENGGUNAKAN PERANGKAT PEMERINGKATAN ALEXA. SMATIKA, 5(1).

15. Rahardja, U., Aini, Q., \& Sulastrini, L. R. (2017). Penerapan Inbound Official Site Sistem Informasi Untuk Meningkatkan Rank Webometrics. Technomedia Journal, 1(2), 105-115. https://doi.org/10.33050/tmj.v1i2.19

16. Zyskind, G., \& Nathan, O. (2015, May). Decentralizing privacy: Using blockchain to protect personal data. In 2015 IEEE Security and Privacy Workshops (pp. 180-184). IEEE.

17. Samaniego, M., \& Deters, R. (2016, December). Blockchain as a Service for IoT. In 2016 IEEE International Conference on Internet of Things (iThings) and IEEE Green Computing and Communications (GreenCom) and IEEE Cyber, Physical and Social Computing (CPSCom) and IEEE Smart Data (SmartData) (pp. 433-436). IEEE.

18. Huckle, S., Bhattacharya, R., White, M., \& Beloff, N. (2016). Internet of things, blockchain and shared economy applications. Procedia computer science, 98, 461-466. https://doi.org/10.1016/j.procs.2016.09.074

19. Wright, A., \& De Filippi, P. (2015). Decentralized blockchain technology and the rise of lex cryptographia. Available at SSRN 2580664.

20. Di Battista, G., Di Donato, V., Patrignani, M., Pizzonia, M., Roselli, V., \& Tamassia, R. (2015, October). Bitconeview: visualization of flows in the bitcoin transaction graph. In 2015 IEEE Symposium on Visualization for Cyber Security (VizSec) (pp. 1-8). IEEE.

21. Hariguna, T., Adiandari, A. M., \& Ruangkanjanases, A. (2020). Assessing customer intention use of mobile money application and the antecedent of perceived value, economic trust and service trust. International Journal of Web Information Systems. http://doi.org/10.1108/IJWIS-12-2019-0055

22. Hariguna, T., \& Ruangkanjanases, A. (2020). Elucidating E-satisfaction and Sustainable Intention to Reuse Mobile Food Application Service, Integrating Customer Experiences, Online Tracking, and Online Review, XXIX, 122-138. http://doi.org/10.24205/03276716.2020.704

23. Hariguna, T., Rahardja, U., \& Ruangkanjanases, A. (2020). The impact of citizen perceived value on their intention to use e-government service: An empirical study. Electronic Government, an International Journal, 16(1), 1. http://doi.org/10.1504/eg.2020.10028551

24. Hariguna, T., Maulana, W., \& Nurwanti, A. (2019). Sentiment Analysis of Product Reviews as A Customer Recommendation Using the Naive Bayes Classifier Algorithm. International Journal of Informatics and Information Systems, 2(2), 48-55.
25. Imron, M., Hasanah, U., \& Humaidi, B. (2020). Analysis of Data Mining Using K-Means Clustering Algorithm for Product Grouping. International Journal of Informatics and Information Systems, 3(1), 12-22.

26. Hariguna, T., \& Rachmawati, V. (2019). Community Opinion Sentiment Analysis on Social Media Using Naive Bayes Algorithm Methods. International Journal of Informatics and Information Systems, 2(1), 33-38.

27. Santiko, I., \& Subarkah, P. (2019). Comparison of Cart and Naive Bayesian Algorithm Performance to Diagnose Diabetes Mellitus. International Journal of Informatics and Information Systems, 2(1), 9-16.

28. Hariguna, T., Hung, C., \& Sukmana, H. T. (2019). The antecedent of citizen intention use of e-government service. TELKOMNIKA (Telecommunication Computing Electronics and Control), 17(1), 202-209. http://doi.org/10.12928/TELKOMNIKA.v17i1.11588 